Khodijah, 2021

Volume 5 Issue 1, pp. 01-22

Date of Publication: $15^{\text {th }}$ March 2021

DOI- https://doi.org/10.20319/pijtel.2021.51.0122

This paper can be cited as: Khodijah (2021). Social Economic Obstacles Education of Fishermen's Children During The COVID-19 Pandemic. PUPIL: International Journal of Teaching, Education and Learning, 5(1), 01-22.

This work is licensed under the Creative Commons Attribution-NonCommercial 4.0 International License. To view a copy of this license, visit http://creativecommons.org/licenses/by-nc/4.0/ or send a letter to Creative Commons, PO Box 1866, Mountain View, CA 94042, USA.

\title{
SOCIAL ECONOMIC OBSTACLES EDUCATION OF FISHERMEN'S CHILDREN DURING THE COVID-19 PANDEMIC
}

\author{
Khodijah \\ Raja Ali Haji Maritime University, Tanjungpinang City, Indonesia, Institute for the Study and \\ Empowerment of Fisherwomen, Indonesia \\ khodijah5778@gmail.com
}

\begin{abstract}
This research focuses on the socio-economic barriers to education for fishermen's children during the COVID-19 pandemic, as well as teacher's strategies to overcome them. The research method used a qualitative descriptive approach. Collecting data using the method of observation and semi-structured interviews with a zoom meeting application to respondents. The school sample was determined purposively, namely the public Madrasah Ibtidaiyah Negeri (MIN) 1 Berakit Village, Bintan Regency, Riau Islands Province, Indonesia. The research respondents consisted of the principal, teachers, students, and representatives of the parents. The findings of this study reveal that fishermen's children experience socio-economic obstacles in the learning process during the COVID-19 pandemic, which is caused by factors of income, education, and their parents' occupation as fishermen. As fishermen, the parents of students have relatively low income and education levels. So that online learning does not take place effectively. The potential of the coastal environment which has beautiful and clean natural characteristics turns out to be able to be a solution in overcoming the socio-economic obstacles of fishermen's
\end{abstract}


children following online learning. Teachers have used it as a collaborative and communicative learning media during the COVID-19 pandemic.

\section{Keywords}

Social Economic, Barriers, Fishermen's Children, Education, Coastal Environment

\section{Introduction}

One in five school-aged students lives in poverty. Dropout rates for children living in poverty have steadily increased even as national high school dropout rates have steadily declined. A family's socio-economic level or status (SES) is defined by the income, education, and occupation of members of the household. A family's SES is typically categorized as either high, middle, or low. It is important for teachers to understand that a relationship exists between SES and educational outcomes (IRISCenter, 2021).

Achieving quality, inclusive education for all reaffirms the belief that education is one of the most powerful and proven tools for sustainable development. This Goal ensures that all girls and boys complete free primary and secondary schooling by 2030. Quality education is one of the 17 Global Goals that make up the 2030 Agenda for Sustainable Development. This is very much in line with the mandate of the 1945 Constitution Article 31 Paragraph 1 states that "Every citizen has the right to education" and Paragraph 2 states that "Every citizen is obliged to attend basic education and the government is obliged to finance it".

The history of Indonesia proves that education is an important means in the struggle and fills its independence; getting a good and quality education is a constant struggle to create prosperity in the future. Quality education has become a demand and needs that must be met by every educational institution, from basic education to tertiary education. One of the efforts made by the government in order to improve the quality of national education in a gradual planned and measured manner in accordance with the mandate of Article 60 of the National Education System Law (hereinafter written as the National Education System Law) Number 20/2003 is accreditation, which determines the feasibility of programs and education units at formal and non-formal education pathways at every level and type of education.

However, since the COVID 19 pandemic entered Indonesia, many important aspects of life have been affected, one of which is education. The government made adjustments to the decision with the Four Ministers regarding the implementation of learning in zones other than red and orange, namely in the yellow and green zones, to be able to carry out face-to-face 
learning with the application of very strict health protocols. The government's main priority is to prioritize the health and safety of students, educators, education personnel, families, and society in general, and to consider the growth and development of students and psychosocial conditions in an effort to fulfill educational services during the COVID-19 pandemic (Ministry of Education, 2019). COVID-19 has actually helped change the socio-economic structure of urban and rural communities. School students who live in rural areas experience various obstacles in the learning process. In fact, according to Santosa, the COVID-19 pandemic situation shows a gap in infrastructure and also Indonesian education institutions that are not ready to face unexpected situations like now (Santosa, 2020). Therefore, schools and school teachers in rural areas are required to be more creative in carrying out the learning process so that students still get good learning material. Therefore, it is necessary to study how the learning process took place during the COVID-19, and how teachers responded to the socio-economic obstacles faced by students during the COVID-19 pandemic.

\section{Research Problems, Limitations, and Methods}

The learning process is an important stage that must be passed well to achieve good learning outcomes, but at this stage always encounters various problems. This study focuses on several research problems and sets limits and research methods to answer the main research questions. Research problems, limitations, and methods are explained as follows:

\subsection{Research Problems}

Berakit Village is one of the fishing villages located in the fishing area of Bintan Regency, Riau Islands Province, Indonesia. The location of Berakit Village is far from the city center of the Regency and Province. More than $80 \%$ of the households living in the Berakit Village work as fishermen, and the socio-economic conditions are relatively low. During the pandemic period, every school in Indonesia is required to implement health protocols during the COVID-19 pandemic as recommended by the government, both schools in urban and rural areas, both in areas with COVID-19 and Zero COVID-19 cases. Berakit Village is one of the villages that does not have a COVID-19 case until the research is carried out. With the implementation of a learning process that must be carried out online, it has an impact on the feelings of boredom faced by school residents, teachers, parents, and students. For parents of students who daily work as fishermen, accompanying and teaching children at home, especially in doing school work, are 
a burden because the level of formal education they have is also relatively low. In addition, parents experience economic constraints in facilitating their children with cellphones to support online learning. For students, online learning has an impact on decreasing the level of student motivation to learn. During online learning, communication problems between school members, teachers, parents, and students experience profound disturbances, collaborative learning patterns that can motivate students to become very important. In the research literature on the learning process during the pandemic, studies of fishermen's children are rarely done. In this study, there are research questions, there are:

1) What is the profile of schools in fishing/fishing villages in the Riau Islands Province, Indonesia

2) What are the perceptions of school residents, teachers, parents, and school students in fishing/fishing villages on the learning process during the COVID-19 pandemic? And what are the socio-economic barriers faced by students?

3) What is the teacher's strategy for building collaborative and communicative learning during the COVID-19 pandemic in fishing village schools?

The research hypothesis as follows:

1) Collaborative and communicative learning is needed by students who face socioeconomic obstacles in education and have an impact on their enthusiasm for learning The utilization of coastal natural resources and marine biota can be a suitable source and learning media to build better intimacy and communication during the COVID-19 pandemic.

\subsection{Limitations}

This study describes the socio-economic obstacles faced by fishermen's children in education and how the teacher's strategies to overcome them in order to meet the quality standards of education. The stages of data collection in the field are limited by the application of social restrictions regulated by the government to prevent the spread of the coronavirus in the community, as well as the difficulty of internet access in research locations that are far from cities. So that all stages of research must comply with health protocols and limit the number of respondents interviewed (school principals, teachers, school committees, students, and parents of students) who are members of the Madrasah Ibtidaiyah Negeri I Berakit, which is a fishing village. 


\subsection{Methods}

This research method uses a qualitative descriptive approach. The entire data collection stages were carried out online using the method of observation, document review, and interviews. Observations were made after reviewing the documents provided by the school, namely by field observations and classroom observations, then conducting interviews in the context of verification, as well as validating data and information provided by the school/ madrasah. The instrument used as a reference for measuring process achievement and learning outcomes is the accreditation instrument from the School / Madrasah Accreditation Board. For the first purpose, school profile data were obtained from data contained in the local district education office school database as well as online surveys. For the second objective, data collection was carried out using an online survey, distribution of questionnaires using a google form, and structured interviews using a Zoom meeting to the principal (1 person), the head of the school committee (1 person as a representative of the parents of students), the head of school administration (1 people), teachers ( 7 people), and school students ( 7 people). For the third purpose of the study, the research data collection used in-depth interviews with the principal (1 person), teacher representatives (1 person), and students of fishermen's children (1 person).

School samples and respondents were determined purposively, representing the fishing village. The school that is the object of the research is Madrasah Ibtidaiyah Negeri Satu (MIN I), Berakit Village, Bintan Regency, Riau Islands Province, where 90 percent of the students are fishermen's children. MIN I Desa Berakit is one of the oldest schools in a fishing village under the Ministry of Religion of Bintan Regency.

Online observations were carried out to see schools' physical condition and the learning process that took place during the COVID-19 pandemic, especially in fishing villages. Then a questionnaire was prepared, which was distributed to respondents using a google form, an interview guide for conducting semi-structured interviews, and online Focus Group Discussions (See Fig. 1). Individual and online in-depth interviews were conducted either through the zoom meeting application or through direct telephone networks to informants, namely teachers and students involved in the learning process during the COVID-19 pandemic.

The data analysis method uses descriptive qualitative analysis, which is visualized in the form of pictures, graphs, tables, and narrative explanations. The perceptions of school residents, school principals, parents, teachers, and students of the learning process during the COVID-19 
pandemic are concluded based on data from interviews conducted, while to determine the value of the quality of the achievement of the national education standard (SNP), the school is concluded from the value of each component. that is measured.

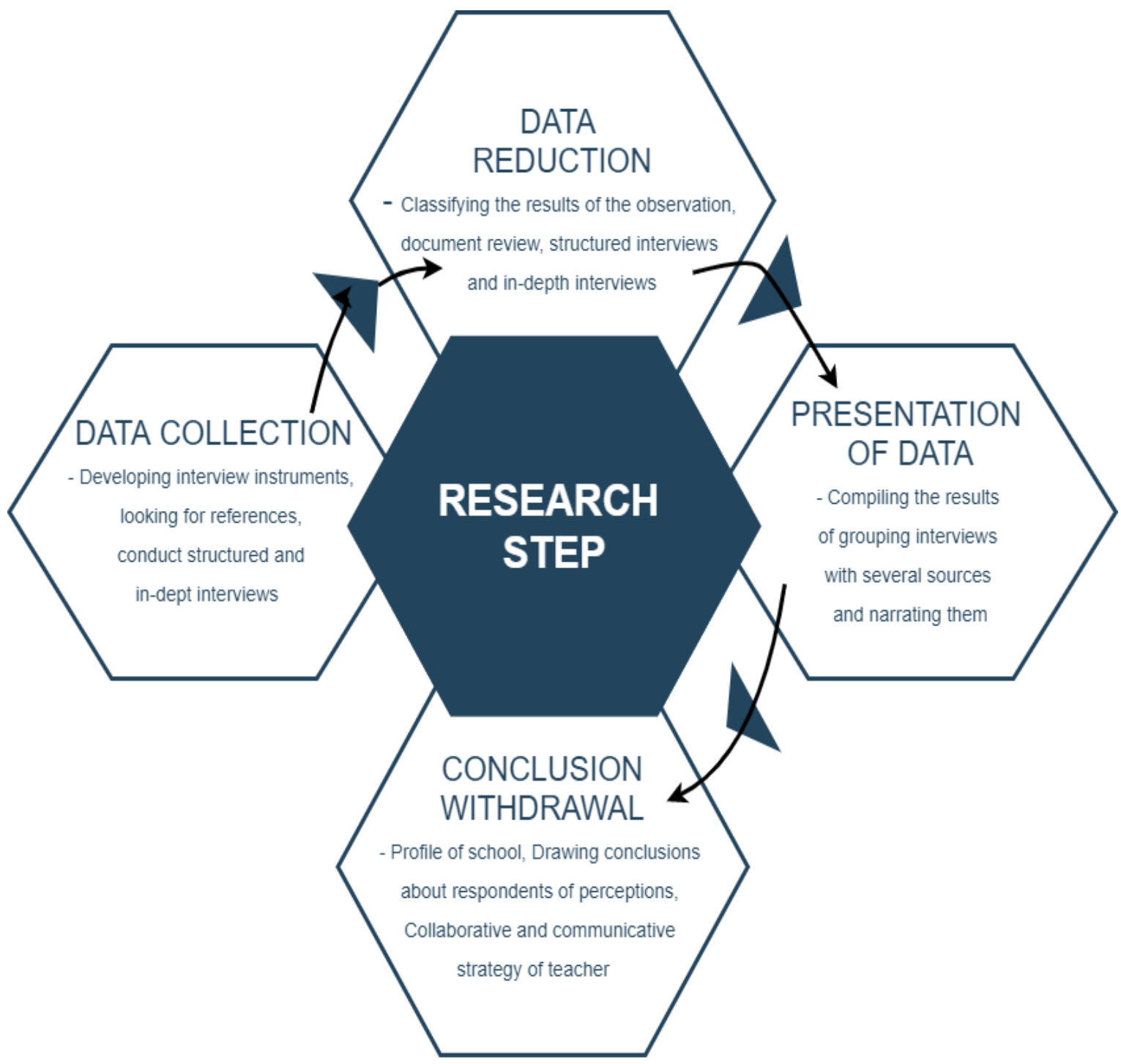

Figure 1: Steps of Research

\section{Results}

After analyzing using a qualitative descriptive method, the findings of the research questions can be described as follows.

\subsection{Profile of Berakit Village and Madrasah Ibtidaiyah Negeri 1 (MIN 1) Bintan Regency.}

Berakit Village is one of the fishing villages located in Teluk Sebong District, Bintan Regency, Riau Islands Province with an area of \pm 53.23 hectares, which existed long before 
independence (1908) but was officially included in Bintan Regency since 2006 with Government Regulation No. 5 of 2006. Geographically it is located at the coordinate point $1^{\circ} 13{ }^{\prime} 37.1$ "N 104 - 33'49.8" E (see Fig. 2) in the outer or northern part of Bintan Island, so it is directly facing the open sea. In its history, Berakit Village as an area bordering Malaysia has an important value during the Ganyang Malaysia incident in 1962. Its proximity to Malaysian waters has made the Berakit area synonymous with smuggling areas. This area has long been synonymous with the crossing locations for illegal Indonesian workers to and from Malaysia. Besides being close to Malaysian waters, Berakit Village also borders the South China Sea. In 1975, Bintan waters, including Berakit Village, were crowded with the arrival of refugees from Vietnam due to the civil war that broke out in Vietnam in 1975. Since the Dutch era until now, there have been eight village heads who have led the Berakit Village.

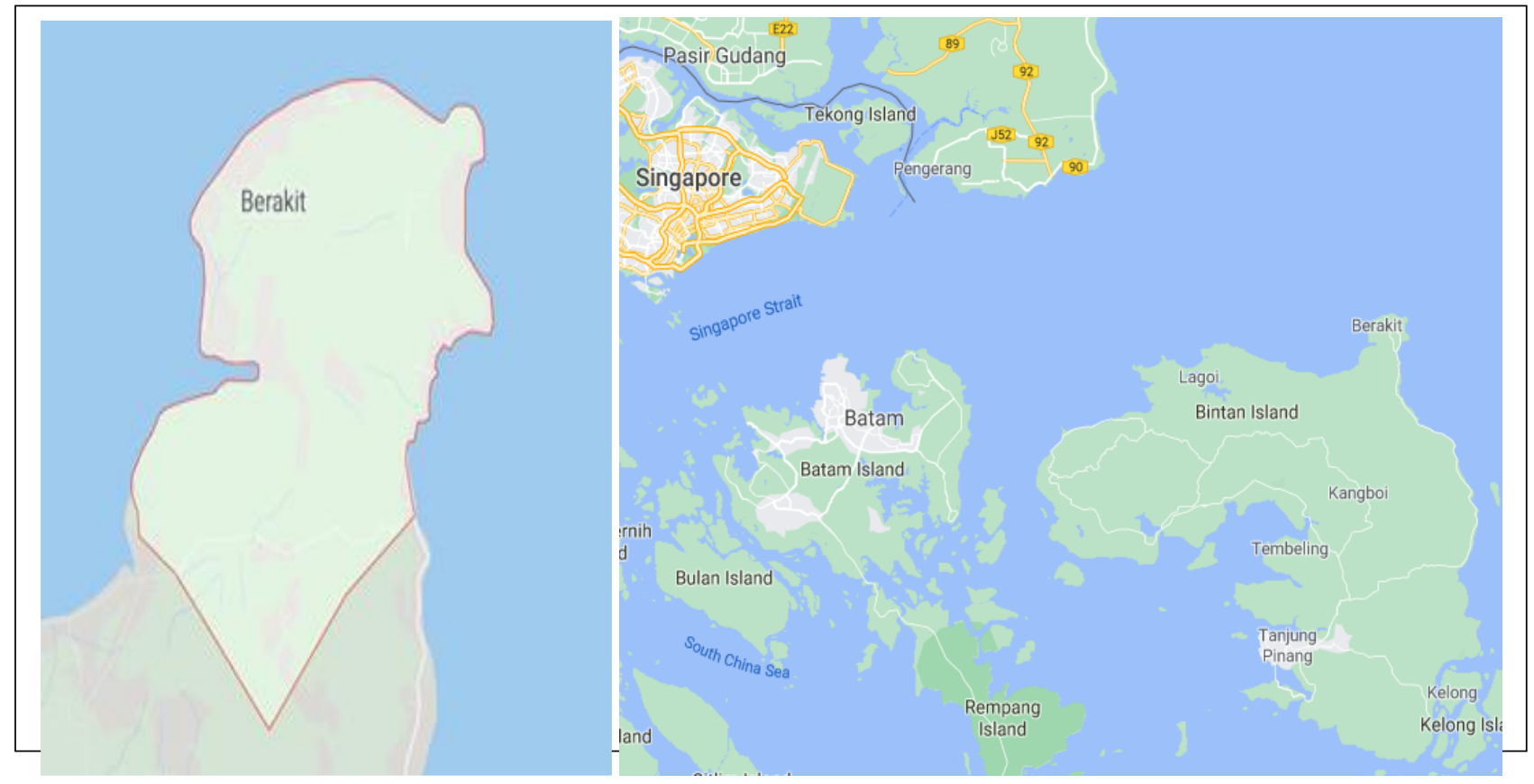

Figure 2: Berakit Village, Teluk Sebong, Bintan Regency, Riau Islands, Indonesia

The total population in Berakit Village until the end of 2018 was 1747 people with an average density of 36 people / square kilometer and a population growth rate of $-0.01 \%$, which indicates that the population rate is slow. The education level of the villagers is relatively low, dominated by those who do not go to school (40\%) and graduate from elementary school (26\%). The low level of education of the population affects the economic structure, dominated by work as fishermen. This can be seen from the houses of village communities that are lined up on the 
shore (see Fig. 3). Berakit Village has the potential for marine, fishery, and tourism resources (beaches, underwater, and mangroves), which are visited by many tourists, so that many resorts exist in this village. However, since the COVID-19 pandemic, the tourist attraction of the Berakit village has seemed very quiet from visitors, both domestic and foreign. Tourist locations that have a beautiful beach are very close to where students live and school. So that the beach becomes a playground for fishermen's children. The houses of village people appear to line up along the coastal fishermen; most of them are fishermen.

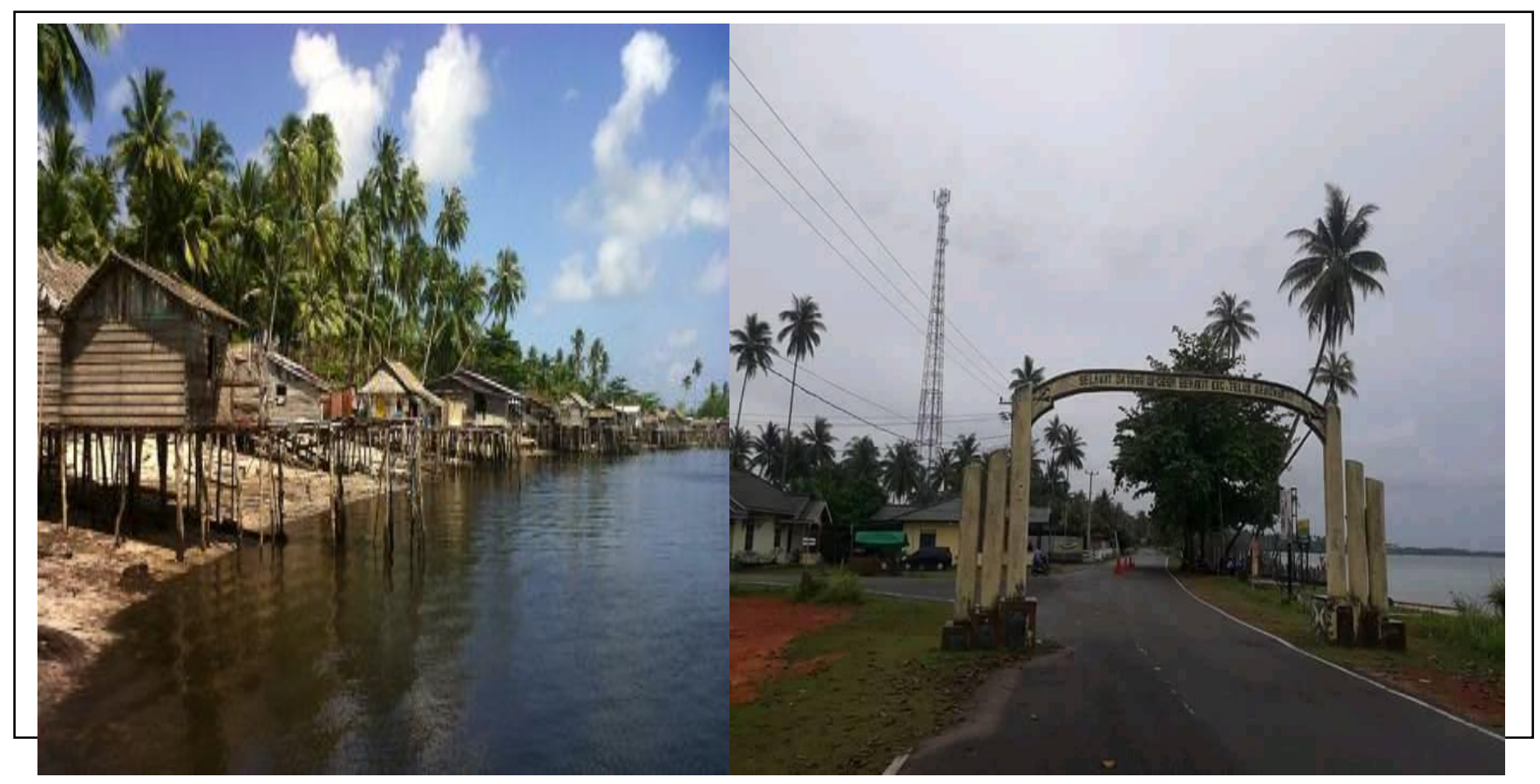

Figure 3: Condition of Community Houses in Berakit Village

The MIN 1 Bintan school is the oldest school in Berakit Village, which was founded in 1951 and was established in 1968. In 2000 this school had a visit from a team of doctors and students from Singapore where free medical treatment was carried out, and in 2016 it was visited by high school students from Kota Tinggi Johor carries out community teaching services and scout cooperation. The school is located quite far from the center of the provincial capital and is in the coastal fishing village. The number of MIN 1 Bintan teachers in six civil servants, three honorariums, one staff civil servant. There are still many school infrastructure facilities that are not yet available such as laboratories, sports fields, prayer room/ mosques, student health units; only classes and libraries are available. However, school conditions are always clean, and the teaching and learning process is going well. Before the COVID-19 pandemic, students were 
always given refreshment through various competitions with the aim of fostering selfconfidence, enthusiasm for fighting, and compassion, such as balloon blowing competitions, cracker eating competitions, sack racing competitions, and tug of war competitions (See Fig. 4 ). During the COVID-19 pandemic, schools seemed deserted, because gathering and playing activities no longer occurred in schools, including the commemoration of national holidays.

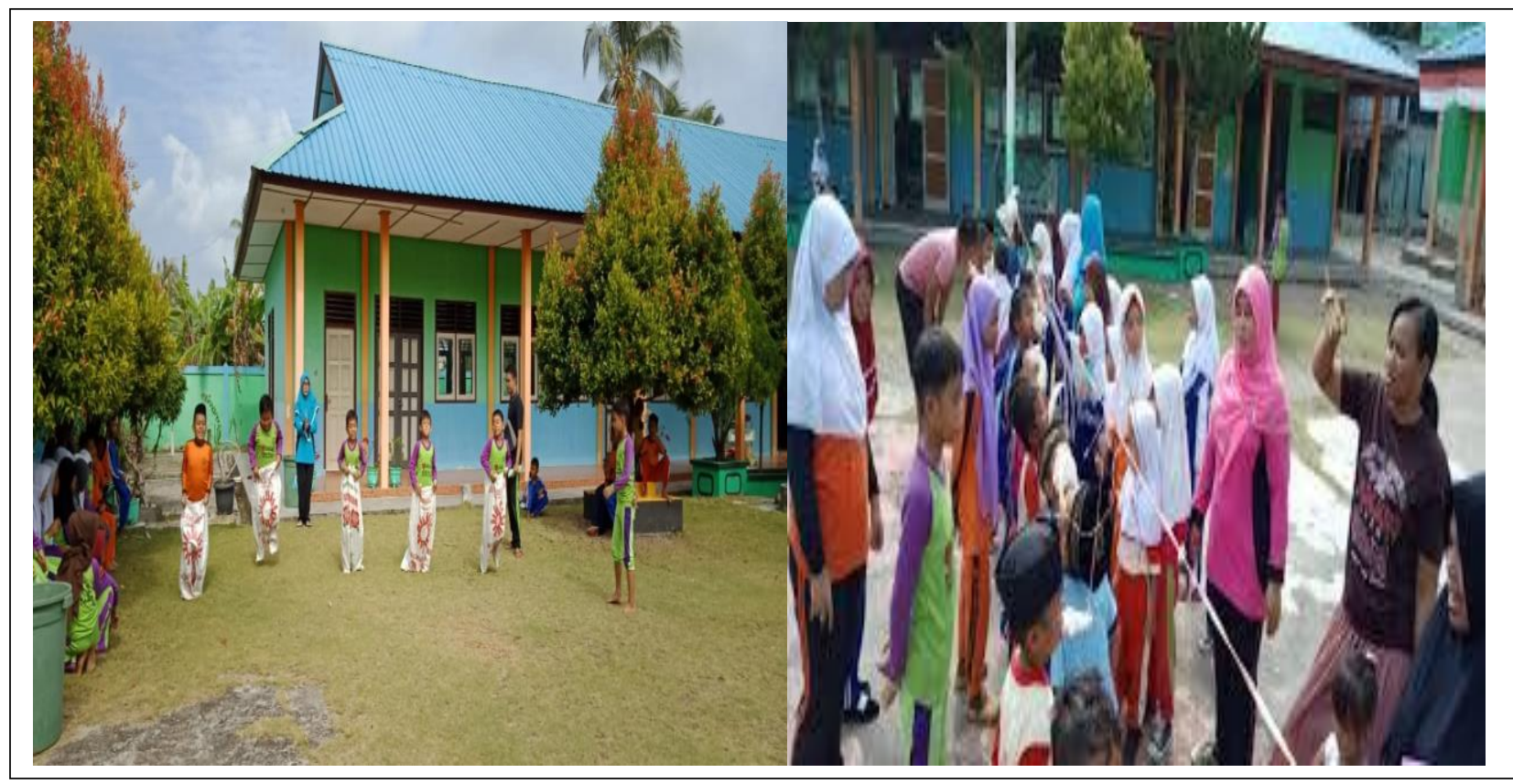

Figure 4: Sack Race and Eat Crackers Competition

\subsection{School Citizens' Perceptions of the Learning Process During the COVID-19 Pandemic}

\section{and the Socio-Economic Barriers Faced by Children of Fishermen}

The widespread of the COVID-19 pandemic has disrupted the education process in rural areas. This can be seen from how the learning process can take place at school and what obstacles are faced by students, especially fishermen's children.

\subsubsection{Perceptions of School Citizens}

The COVID-19 pandemic has not stopped at national borders. It has affected people regardless of nationality, level of education, income, or gender (Schleicher, 2020). The increasing number of COVID-19 cases that have occurred in Indonesia, including Bintan Regency (Fig. 5), has led to increased concerns in various aspects of life, especially the aspect of education. The government, through a Joint Decree of 4 ministers, namely the Minister of Education and Culture, the Minister of Religion, the Minister of Health, and the Minister of 
Home Affairs, has issued guidelines for the implementation of education during the 2019 Corona Virus Disease (COVID-19) pandemic.

All components of society and educational institutions are expected to comply with these guidelines. Likewise, good teachers who work at Madrasah Ibtidaiyah Negeri 1 Desa Berakit Bintan have carried out the learning process following the COVID-19 guidelines and protocols. Therefore, students' perceptions can describe how an effective learning process can take place (Kaltsas, 2020).

\section{a. Principal's Response}

The results of interviews with school principals found that they experienced a dilemma in making school decisions and policies related to the impact of the pandemic so that the principal only waited for instructions and direction from the education office, which had a mandate from the central government. During the COVID-19 pandemic, it is difficult for school principals to apply awards and sanctions to school members, both teachers, education personnel, and students. The principal always resolves obstacles, obstacles, and problems encountered during the pandemic in the learning process by means of deliberation and consensus. Teachers and education personnel who attend school take turns in order to avoid crowds in the teacher's room and office. Communication is more often done online using the school group WhatsApp. The principal assessed that the online learning process carried out on elementary school/madrasah ibtidaiyah students were not yet effective and were worried that there would be a decline in students' academic abilities even though the learning process could take place every day. Elementary school students get bored quickly with such learning patterns because they can only do assignments and are not active in the question and answer process between teachers and students. In addition, $96.15 \%$ (125 people) of students whose parents work as fishermen with an average education have graduated from elementary school, some have never taken formal education, and $4 \%$ or 5 of their parents work as civil servants. This condition will be difficult for the effectiveness of the learning process from home because students do not get assistance from people who are competent in their fields. In addition, the fishermen's economic condition is relatively low, which affects their ability to buy cellphones and internet pulses, as shown by onethird of students who do not have cellphones.

The government, through the Ministry of Education and Culture, has provided internet quota packages to students, but it cannot be used by teachers and students of the fishing village 
because the internet and cellphone signals owned by students do not support the coastal village. So that not all students can take part in online learning, so teachers need to find solutions so that the learning process can take place. The principal understands the difficulties faced by teachers and students with the online learning system so that teachers are given the freedom to be creative in implementing the learning process.

\section{b. Teacher's Response}

The results of interviews with teacher respondents showed their dilemma towards the learning process during the COVID-19 pandemic, on the one hand, they agreed that face-to-face learning was the best way to educate elementary school children, but they also objected to faceto-face learning during the pandemic, and continue to increase. They are very worried that the opening of face-to-face learning will make new cluster schools spread COVID-19. So that inevitably every teacher must carry out the learning process online. In the online learning process, the teacher complained about several obstacles faced, such as:

1) Ownership of online learning tools. The habit of teaching with a face-to-face system causes teachers to rarely use laptops in their work. And some of the teachers do not have laptops and use laptops as a tool for teaching.

2) Information and Technology Capabilities. Not all teachers have good skills in the use and utilization of IT in the learning process, so the teaching process is carried out by giving assignments through the WA group and having students work at home and take them back to school. This is mostly done by senior teachers who have taught for decades, but for teachers who are relatively young, they use google classrooms, slides, and youtube when teaching.

3) Internet access. None of SDN 011 Tanjungpinang teachers complained about the internet network, but for MIN 1 Bintan teachers all complained about the difficulty of internet access, which was difficult in the village.

4) Control of students. With a communication model that dominates the learning process, teachers find it difficult to monitor student activities, their level of understanding, independence, honesty, and abilities.

5) Mastery of Information and Technology skills. Mastery of skills is very important (Cámara-Zapata, Puerto-Molina, \& Brotons, 2020), especially for teachers as educators. 
Most of them said that they had not mastered many online learning applications. They need various training to optimize the implementation of online system learning.

\section{c. Parents' Response}

The results of interviews with students 'parents showed that parents find it difficult to arrange a time to accompany their children to study at home, in addition to the current school subject matter they do not understand well because parents' education is also relatively low. The difficulty in managing time is due to the students' parents spending their time working to support the family. As a fisherman, sometimes when he goes to sea for a few days, he comes home to gather with his family. Meanwhile, the mother is busy with household affairs and helps the family economy. Almost all parents really hope their children can learn like before the COVID 19 pandemic. Online learning for parents only adds to the burden for them. In addition, the internet network in the village is also not smooth, so that the free internet package provided by the government cannot be of maximum benefit for children's learning uses. Due to economic limitations, parents complain a lot about the difficulty of facilitating their children to learn to use cell phones, so it is not uncommon for family members to use one cellphone alternately.

During the COVID-19 pandemic, many parents complained about the disruption of communication with the school using the online system. Because not all parents have cellphones to communicate with, the learning process carried out by the teacher uses more of the way of giving assignments via WhatsApp. With this pattern for the parents of students, the learning process cannot take place effectively, so it is not uncommon for the assignment was given by the teacher to not finish according to the given time. Parents hope that teachers can provide more interesting learning and can make their children excited to learn. Science learning is the most interesting subject for their children because besides watching learning videos, students can also learn directly from nature.

\section{d. Student Responses}

The results of interviews with student respondents revealed that they felt uncomfortable and were getting bored with online learning. Many of them said it was difficult to understand the subject matter with the online system compared to face-to-face learning with teachers in class and could meet many friends. The online learning process experienced by students received more assignments from teachers who were informed via WhatsApp groups. Only a few teachers were there to share learning videos made by teachers, such as science, social studies, and religion 
lessons. Students who live in coastal villages that are far from urban areas have difficulty accessing the internet network. Besides that, they only have one cellphone in one house, so they use it alternately with their siblings in junior high and high school (See Fig. 5). This is also an obstacle for fishermen's children to take part in the online learning process. So the solution taken by some students is to go directly to the teacher at the school because the school is very close to home. Students revealed that studying online at home was only limited to making assignments, so they had more time to play at home, and there were children who revealed that cellphones were mostly used to play online games; there was no time to make friends because they had to always be at home. Students are very happy when learning science that their teacher takes them to the beach to get to know the ecosystem, habitat, and species of marine life around the coast.

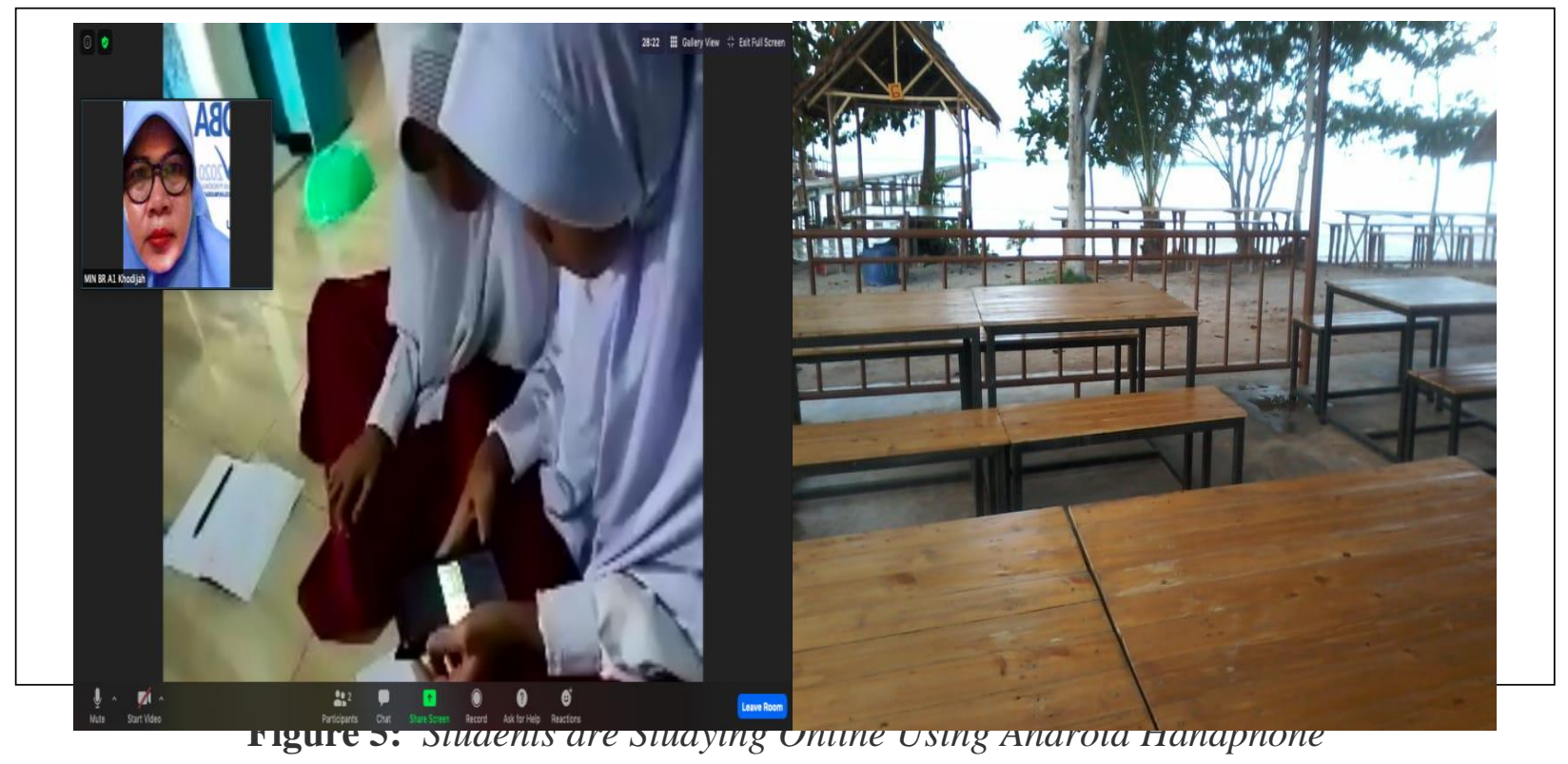

All students who became respondents expressed their joy in being able to study in the open, such as utilizing the beach and the surrounding biota for learning Natural Science. All students conveyed that they felt more familiar and excited about participating in learning with teachers and friends. At Madrasah Ibtidaiyah Negeri I Bintan, in online learning, there are $85 \%$ of teachers using the WhatsApp application, and 15\% using more diverse applications such as interactive video (youtube), classroom applications, digital and natural collaborative learning.

\subsubsection{Socio-Economic Barriers Faced by Fishermen's Children in Education During the} COVID-19 Pandemic

The level of socio-economic status is determined by the income, education, and occupation of household members, which are categorized as high, middle, or low. 


\section{a. Profession}

The Parents' Profession of students is dominated by work as fishermen (> 90\%). All fishermen who are parents of students are small-scale fishermen with inadequate fishing fleets and equipment - working as a fisherman causes a lot of time spent by the parents of students to go to sea. In contrast, the fishermen's wife as the student's mother does various jobs and responsibilities of the husband while the husband is fishing (days). This condition makes it difficult for a mother to focus on guiding her child to study at home during the COVID-19 pandemic. Sometimes students help with their mother's work at home so they can't focus on studying.

\section{b. Income}

Parents' income as fishermen is relatively low, and it is difficult to meet all the household's socio-economic needs. The fishermen's income depends on the wind season, the fleet, and the fishing gear they use. Fishermen's poverty also causes debt dependence to meet life's necessities on the "tauke" that is collector traders who buy their catch and have strong social ties from generation to generation. Low incomes make it difficult for parents of students to meet their children's needs in online learning, such as buying gadgets (cellphones) and internet pulses. More than $75 \%$ of the students interviewed stated that it was difficult to learn online because they did not have a device, and it was not uncommon for one device to take turns with their siblings who went to school as well. Apart from the difficulties of learning media, living far from the city center also makes it difficult for students to get smooth internet access to study online. The COVID-19 pandemic also worsened fishermen's income, due to restrictions on sea transportation, which made it difficult for fish sales to flow outside the region. So that the "tauke" buys fish at a lower price than usual, apart from that, it is also difficult for fishermen to get boat fuel as usual.

\section{c. Education}

The education of the head of the family and members of the fishing household is relatively low, namely completing elementary school (SD) and junior high school (SMP). This is that all household members are often involved with their father's work as fishermen from generation to generation, from pre-sea, to sea and post-fishing, so that the education of fishermen's children is left behind due to dropping out of school and not continuing to a higher level. Parents and other family members' low education makes it difficult for students to get 
assistance when studying at home, especially with the online learning system. Low education causes low technology skills in the use of online media by parents and other members (older sisters or brothers) in the family.

\subsection{Teacher's Solution: Utilization of Coastal Environment as Learning Communication Resources and Media}

The socio-economic obstacles faced by students require great attention and creativity from the teacher. Teachers must be able to build strong relationships with students so that they are able to identify the needs and problems faced by students. Thus teachers find it easier to find solutions to problems faced by students. The teacher can provide a comfortable, safe, motivating, and engaging environment for students to participate actively in the learning process.

Beaches and marine life as marine resources found along the fishing village are sources and media of learning communication that can be used by school teachers who teach in fishing villages. Fishermen dominate the livelihoods of the parents of students in fishing villages with relatively low education. This greatly affects the motivation and enthusiasm for learning of fishermen's children at school, because it is not uncommon for fishermen's children to be involved in their parents' work before and after fishing.

This condition is used by Madrasah Ibtidaiyah Negeri I Bintan teachers in the learning process, such as in science lessons. Students are invited to get to know marine biota directly from their ecosystem on the beach. In this open space, students can interact actively with their teachers because of the development of communication and familiarity between teachers and students. With a fishermen's child background, it can make it easier for students to understand the teacher's science subject matter. Learning atmosphere like this is very fun, fresh, and free from air pollution, this learning process is difficult to find in urban areas. Limited laboratory facilities in schools are no longer an obstacle for fisher children to learn science.

The learning process that has been carried out by the teacher at MIN 1 Bintan shows positive results on motivation, enthusiasm for learning, and learning outcomes obtained by students. Students get meaningful material and direct experience with direct observation of the coastal ecosystem. In addition, the teacher also implements the making of videos of their learning results and then posts them on the teacher's Instagram, then the children are full of pride to see their video learning in a fun atmosphere. The results of observations and interviews conducted revealed that students were again excited by teachers who were full of creativity and 
inspiration in learning. The learning outcomes also prove that students quickly understand the learning material with satisfactory grades.

\subsection{Learning Outcomes}

To realize quality education, every school must be able to meet national education standards. The eligibility of the formal primary and secondary education units must refer to the National Education Standards (SNP). It cannot be denied that teaching is a business that is never simple. A teacher must have not only master knowledge of the subject areas being taught or knowledge of various pedagogical sciences but can convey the knowledge taught with the right strategies and methods. From the results of the school/madrasah report card quality assessment survey conducted by the Education Quality Assurance Institute from 2016 to 2018 in all elementary schools in Bintan Regency, it is known that the standard of educators and education personnel always has the lowest score of all the standards to be achieved (See Fig. 6). The role of the teacher is primarily an occupational role, predetermined by the nature of schools and of teaching, teachers interpret their roles in different ways depending on the kinds of institutions in which they work, the teaching methods they employ, their personalities, and their cultural background (Saad ALRowais, 2015). In teaching-learning, teachers should not only focus on cognitive but also affective and moral aspects (Haq, 2017). This shows the importance of the learning process supported by the competence of teachers who teach students in schools. The achievement of national school education standards will be increasingly difficult to achieve if it is not supported by complete and good school facilities and infrastructure. Although these two standards are in low criteria, the learning process standard gives the best score. From the results of the interview, it is known that with limited facilities and infrastructure, students are still motivated to learn, and teachers carry out their learning tasks patiently and creatively. This is inseparable from the support of school management, parents, and the community around the school environment. Rural life causes children of primary school age to be less affected by external negative influences. This is shown by the attitude and morals of students who are very good in their interactions in the school environment and the community. 


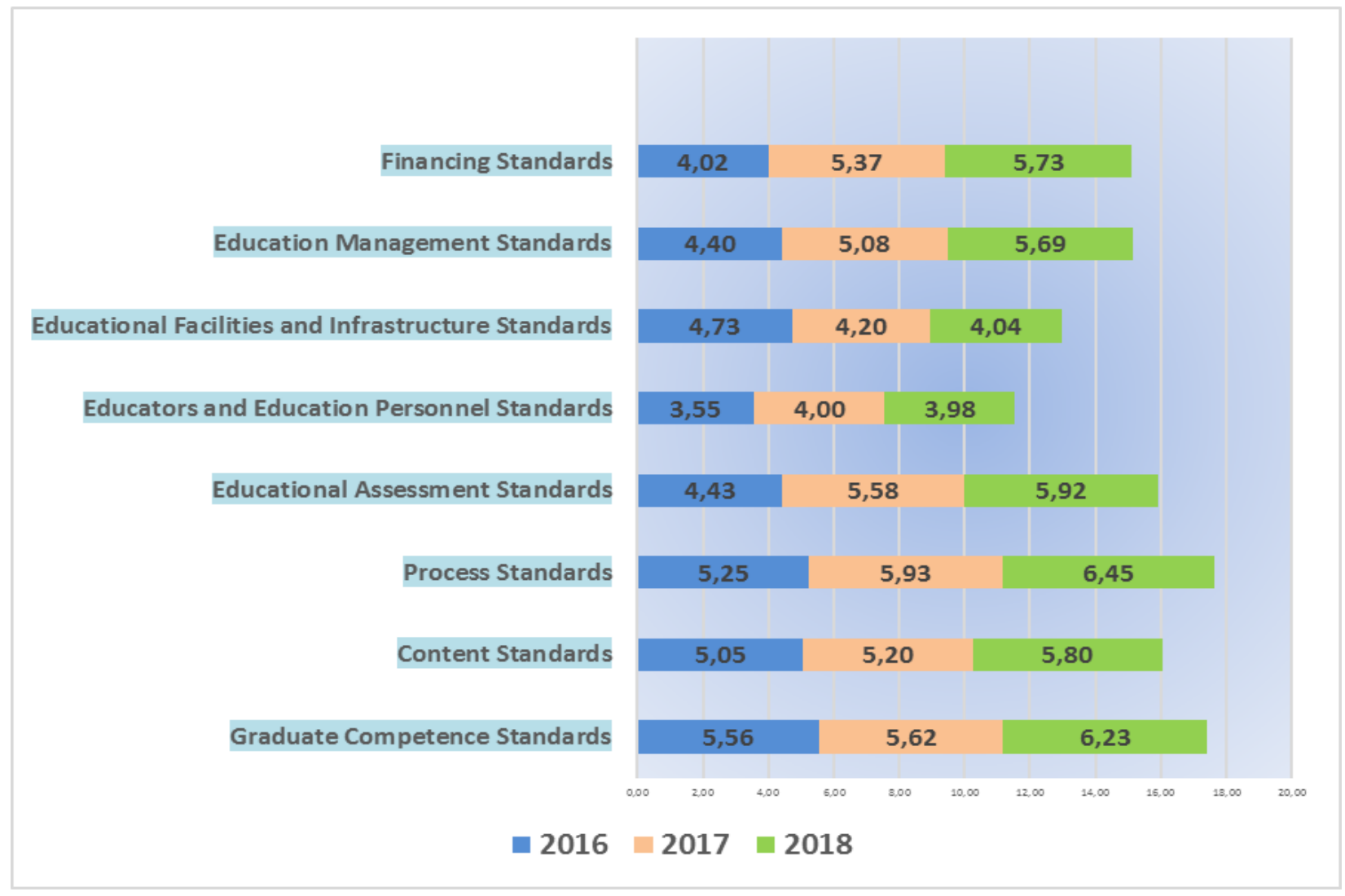

Figure 6: Achievement of National Education Standards for Elementary School / Madrasah in

Bintan Regency (Source: Educational Quality Assurance Institution, 2018)

The problems of teachers and staff, as well as educational facilities and infrastructure, are the two standards that need attention. Although the internet is smooth and students are economically capable, if the teacher does not have good competence, it will affect the learning outcomes achieved by students. This is quite concerning, especially during the COVID-19 pandemic, the ability and competence of teachers is an important challenge to realize quality education.

\section{Discussion}

The development of the COVID-19 pandemic case in Indonesia has led to a major transformation in the learning process at all levels of education in Indonesia, from face-to-face or offline teaching and learning to online (online). This was done solely to inhibit the rapid expansion of the corona virus's spread, especially among school residents. Suddenly and without preparation, all students and teachers learn from home. This causes the government to loosen the 
education assessment system according to emergencies as long as learning can continue without being burdened with competency attainment. As stated in the guidelines for delivering education during the COVID-19 pandemic (Ministry of National Education, 2019).

Digital learning is a technology in education that has become an important solution during the COVID-19 pandemic, but this research reveals that it is not yet effective for all levels of education and regions in Indonesia. Different previous studies have shown that digital learning in high schools and higher education can be carried out effectively, especially in urban areas. Where digital learning that is applied effectively can increase student engagement, retention, and learning outcomes, but digital learning technology needs to be supported by developing learning spaces (Heider, 2015). And the reverse can also be the use of the internet to create pressure (Lai \& Lee, 2019) especially for fishermen's children who live in remote villages.

The solutions to overcome the problems of the learning process during the COVID-19 pandemic in rural fishing areas in Indonesia can be done several things:

a) Improve communication and active participation of students in learning; The length of time students are in front of the screen, and the lack of communication between parents at home causes their dislike of physical activity so that students lose close friends. This study reveals the need for teacher-parent cooperation as an intervention strategy to promote physical activity, especially sports, for students during learning at home (Sawa, Sekine, Yamada, Fukazawa, \& Hiraku, 2020). In addition, teachers are also required to be fair to students to participate actively (Cuervo, 2020); (Nassim, 2018).

b) Strengthening cooperation between teachers and parents; ICT and digital learning are tools for communicating and sharing according to their respective roles (teachers, academics, parents, experts, and institutions). Therefore it needs encouragement so that each of these elements can use these technologies (Barolli \& Poniszewska-maranda, 2020).

c) Increase the competence of teachers and educational staff; The teacher as a determinant of student potential development is not enough to just teach (transfer of knowledge). However, teachers are required to continuously develop their intra and interpersonal skills (Jaenuri, 2017). Teachers' readiness, especially in the blended learning transition in the midst of the COVID-19 crisis, is needed (D. Anoba \& Cahapay, 2020). Teachers with good competence will certainly have better readiness too. 
d) Providing infrastructure to support online learning in fishing villages by the government; The education sector basically lives in a complex network context involving the socioeconomic situation and the surrounding community environment. A family's economic class has a major impact on the length of schooling and the quality of an individual's education (Santosa, 2020).

e) e) Collaborative communication between digital and natural learning by utilizing natural environment sources and media; Information and Communication Technology has created new opportunities to read and write text in social spaces that have changed the way children learn. There are two spaces for literacy, namely being promoted within schools and based on printed texts, and another developing outside of schools and supporting digital and information literacy (Moreno-Morilla, Guzmán-Simón, \& GarcíaJiménez, 2021). In other studies, it is revealed that collaborative learning has great potential in higher education. Collaborative means are forming groups, the relevance of practice with the use of technology, changing the role of teaching and managing learning (Herrera-Pavo, 2021). The practice of social innovation plays an important role in the achievement of education and cultural outcomes, namely by promoting social transformation that provides an open and inclusive learning environment. A "learning environment" for addressing social exclusion encourages the creation of highly accessible spaces filled with cultural and educational functions (Federica Fulghesu, 2017). It is different from the findings of this study that what is meant by collaborative is applied in the sources and media of communication used in elementary school student learning. The learning process is carried out in several literacy spaces, namely digital spaces, houses, and open-air (beaches), with an interactive communication model. So that students can participate actively during the learning process. Its implementation still adheres to the COVID-19 protocol and is carried out once a week, in villages that still have zero corona cases and are far from the city center.

f) Teacher's hard skills and soft skills, educators' soft skills have a significant effect on student academic stress (Miyono, 2019) especially dealing with students who are at risk and vulnerable (Zlatkova-Doncheva, 2019), like being affected by stress due to online learning over a long period due to the COVID-19 pandemic. So it needs to be encouraged 
so that every teacher can master hard skills and soft skills in the teaching and learning process.

\section{Conclusion}

Education is the most important element in the development of coastal communities in small islands. The socio-economic obstacles faced by fishermen's children in pursuing education require serious attention from various parties, especially facing the impact of the COVID-19 pandemic. The teacher has a very important role in encouraging the enthusiasm of learning fishermen's children to stay in school. Teacher creativity is highly demanded in the learning process, given the limited socio-economic abilities of students.

The results of this study found that the existence of schools in fishing villages with unique coastal environmental characteristics can be used to overcome social and economic barriers faced by fishermen's children. The creativity of the teacher who takes advantage of the beach atmosphere and the marine biota that surrounds it is actually able to create a closer relationship and better communication between the teacher and students so that students become more enthusiastic. This is a solution to the problem of implementing online learning for students in rural areas. Natural literacy has a significant effect on enthusiasm, motivation, and student learning outcomes. Therefore, learning methods during the COVID-19 pandemic need to be adapted to the social, economic, and cultural conditions of people living in rural areas.

\section{Acknowledgment}

This research received data support from the Institute for Quality Assurance for Education, Riau Islands Province, and financial support from the Institute for the Study and Empowerment of Fisherwomen, Indonesia.

\section{REFERENCES}

Cámara-Zapata, J. M., Puerto-Molina, H. M., \& Brotons, J. M. (2020). Skills Analysis in an Engineering Degree Using Fuzzy Logic. a Case Study. INTED2020 Proceedings, 1(3), 1124-1131. https://doi.org/10.21125/inted.2020.0396

Cuervo, H. (2020). Rethinking teachers' production of social justice in rural schools. 
International Journal of Inclusive Education, 24(13), 1357-1371. https://doi.org/10.1080/13603116.2018.1526338

D. Anoba, J. L., \& Cahapay, M. B. (2020). the Readiness of Teachers on Blended Learning Transition for Post-Covid-19 Period: an Assessment Using Parallel Mixed Method. PUPIL: International Journal of Teaching, Education and Learning, 4(2), 295-316. https://doi.org/10.20319/pijtel.2020.42.295316

Federica Fulghesu, et al. (2017). New Metropolitan Perspectives: Can Cities Become "Inclusive Learning Environments"? In Smart Innovation, Systems and Technologies (Vol. 178). Retrieved from http://www.isth2020.org/single-post/2017/02/12/?New-MetropolitanPerspectives?-Presentazione-Della-III-Edizione-Del-Simposio-Internazionale

Haq, S. K. (2017). Kepribadian Guru ideal dalam Kitab Abadu Al Alim Wa Al Muta'allim. Jurnal Smart, 03(1). Retrieved from http://blasemarang.kemenag.go.id/journal/index.php/smart

Heider, J. S. (2015). Using Digital Learning Solutions to Address Higher Education's Greatest Challenges. Publishing Research Quarterly, 31(3), 183-189. https://doi.org/10.1007/s12109-015-9413-8

Herrera-Pavo, M. Á. (2021). Collaborative learning for virtual higher education. Learning, Culture and Social Interaction, 28(June 2020), 100437. https://doi.org/10.1016/j.lcsi.2020.100437

IRISCenter. (2021). Page 6 : Socioeconomic Factors diversity in their classrooms? Retrieved from https://iris.peabody.vanderbilt.edu/module/div/cresource/q2/p06/

Jaenuri. (2017). Teacher Soft Skill Development. Ta'allum: Journal of Islamic Education, 5(1), 123-140. https://doi.org/10.21274/taalum.2017.5.1.123-140

Kaltsas, A. (2020). Vocational High Schools Students' Views on the Circulation of the Electric Current in the Electronic Control Unit (Ecu) of the Modern Cars. PUPIL: International Journal of Teaching, Education and Learning, 4(3), 01-13. https://doi.org/10.20319/pijtel.2020.43.0113

Lai, Y. L., \& Lee, J. (2019). Trend of Internet Usage and Learning Style of Digital Natives. PUPIL: International Journal of Teaching, Education and Learning, 3(2), 94-102. https://doi.org/10.20319/pijtel.2019.32.94102 
Ministry of Education and Culture of the Republic of Indonesia. (2019). Guidelines for implementing enrichment learning. 2019.

Miyono. (2019). Effect of Educator's Soft Skill and Self Efficacy on Student's Academic Stress at State Islamic Senior High School (MAN) in Semarang Regency. Jurnal Smart, 05(01), 45-56. Retrieved from http://blasemarang.kemenag.go.id/journal/index.php/smart

Moreno-Morilla, C., Guzmán-Simón, F., \& García-Jiménez, E. (2021). Digital and information literacy inside and outside Spanish primary education schools. Learning, Culture and Social Interaction, 28(April 2020), 100455. https://doi.org/10.1016/j.lcsi.2020.100455

Nassim, S. (2018). Digital Storytelling: an Active Learning Tool for Improving Students' Language Skills. PUPIL: International Journal of Teaching, Education and Learning, 4(1), 14-29. https://doi.org/10.20319/pijtel.2018.21.1429

Saad ALRowais, A. (2015). Roles of a Teacher in Colleges of Education. International Journal of Technology and Inclusive Education, 4(2), 654-660. https://doi.org/10.20533/ijtie.2047.0533.2015.0086

Santosa, A. B. (2020). Potret Pendidikan di Tahun Pandemi: Dampak COVID-19 Terhadap Disparitas Pendidikan di Indonesia. CSIS Commentaries, 1-5.

Sawa, S., Sekine, M., Yamada, M., Fukazawa, Y., \& Hiraku, Y. (2020). Social and family factors as determinants of exercise habits in Japanese elementary school children: A crosssectional study from the Super Shokuiku School Project. Environmental Health and Preventive Medicine, 25(1), 1-14. https://doi.org/10.1186/s12199-020-00892-3

Schleicher, A. (2020). COVID-19 on Education Insights from Glance 2020. 1-31. Zlatkova-Doncheva, D. K. (2019). Language Impact Towards Social Behavior of At-Risk Children. PUPIL: International Journal of Teaching, Education and Learning, 3(1), 01-21. https://doi.org/10.20319/pijtel.2019.31.0121 